6

\title{
DETERMINANTS OF SECTORAL FIXED INVESTMENT EXPENDITURE BY FOREIGN COMPANIES NIGERIA: AN ECLECTIC APPROACH
}

\author{
Dr G. O. AtoyeM and Dr M. O. Qdedokan
}

Introduction and a brief Literature Review

\section{PREAMBLE}

The need to investigate the factors determining private fixed investment outlays can hardly be over-emphasised considering the role of this variable in macroeconomic policies, A realisation of this has prompted several empirical studies: using the data for the developed countries.

A survey of such studies up till 1953 is contained in Mayer \& Kuh (1957). This was updated to 1960 by Efeener and Strotz (1963). Later reviews for pre-1970 have been undertaken by Lund (1971) and Jorgenson (1971), while the survey by Rowley and Trivedi (1975) included those studies in the early 1970s. There has been continuation of these-empirical studies since the 1970s. Some studies on this subject employing the data on developing countries tan also be spotted especially from the 1970s. The major ones that have come to our notice include those undertaken by Behrman (1972) for Chile; Bilsbor-row (1977) for Columbia; Leff and Sati (1980) for Argentina, Brazil, Chile, Costa Rica, Israel and Taiwan; Akinnifesi (1981) for Nigeria as 
well as Wai and Wong (1982) for Malaysia, Thailand, Mexico and Korea. However, the studies based, on developing countries, are still fewer than those based on the developed countries.

These studies can be divided into two: those under the first category are dogmatically based on a particular narrow theory of investment bahaviour in explaining the desired level of capital stock while those under the second category borrow ideas from the various narrow theories contained in the category. This is why this category is often referred to as one based on an eclectic approach.

\section{Studies based on a particular narrow Theory of Investment Behaviour}

Surveys of this category of studies as contained in Jorgensen (1971) and Aklnnifesi (1981), have identified four types:

(a) The Accelerator Theory This asserts that an increase in the rate of change of output is required to increase the level of investment. This theory dates as far back as the rigid accelerator model of Clark (1917) and subsequent flexible accelerator model of Chenery (1952) and Koyek (1954).

(b) The Liquidity Theory According to this theory, desired investment is a positive function of increase in internally-generated funds. This relationship can be credited to the work of Mayer and Kuh (1957) and other early writings on the subject. Later, the significance of availability of other sources of funds was also emphasized as an important determinant of investment expenditure especially in the context of imperfect financial markets that characterise the developing economies. For example, Leff and Sati (1980) as well as Wai and Wong (1982) explained investment outlays in each of the selected developing countries in terms of the flow of domestic credits and net foreign capital inflows, among others. In short, both the internal and external sources of cash flow have now found their way in the investment expenditure model.

(c) The Expected Profit Theory This theory states that desired investment is a positive function of the expected profit. This means that an increase in the envisaged rate of profit is likely to justify an increased rate of investment. Several measures of the expected profit employed include the most recent past profit performance, current profit performance, stock market valuation of a company, and indices of the level of share prices.

(d) The Neoclassical Theory This theory specifies desired investment 


\section{Annals of the Social Council of Nigeria}

as a negative function of the user cost of capital Le. a combination of interest rate and price of capital services net of capital gains on the investment. The cost of finance in the form of interest rate was recognised by Keynes (1936) as the main determinant of investment expenditures. But this concept of the cost of capital has been extended to include the relative price of capital goods as compared with the price of output. This concept makes the user cost of capital a combination of the borrowing cost and the relative price of capital services which has been adjusted for any capital gain. This thought forms the basis of neoclassical investment theory as typified by the work of Jergenson (1967) in which the desired capital stock was derived as a negative function of the user cost of capital.

\section{Studies based on the Eclectic Approach: The Springboard of the present study}

As pointed out earlier, this category of studies does not subscribe to any of the narrow theories described above. Instead, it is based on the premise that each of the theories is likely to have something to contribute to a knowledge of the determinants of investment expenditure and, therefore, strives to blend the possible contributions of these theories into a unified whole. It is based on the awareness that a rigid adherence to any of the theories is not likely to be of much practical policy use. It also recognises the possible influences, on investment expenditure, of other factors or variables not explicitly recognised in any of the existing four narrow theories reviewed above. Notable among such other factors are the following:

(a) BALANCE SHEET RISK VARIABLES: The risk inherent in the structure of the balance sheet is often considered as a limiting factor on the desired stock of capital goods, and hence on investment expenditures. The risk is normally measured by either a form of gearing ratio or an inverse of a current asset ratio. The higher this ratio, the less the desire to raise further finance with which further investment expenditures are customarily financed.

(b) FOREIGN RESERVE LEVEL: This idea was first suggested and tested for (with positive results) by Bilsborrow (1977) in his study of investment expenditures by Columbian manufacturing firms. According to this thought, the availability of foreign reserve is expected to influence the ability of firms to import capital goods and hence implement their investment plans. The inclusion of this variable as a determinant of investment fits well into the circumstances of most developing. 
countries since most machinery and equipments have to be imported.

(c) LAGGED VALUE OF THE STOCK OF CAPITAL A distributed lag of investment expenditure model in which the lagged values of the capital stock enters an investment expenditure equation negatively is often formulated. However, a reason for a positive relationship between the lagged value of capital stock and current value of investment expenditure has been adduced by Wai and Wong $(1982 ; 34$, footnote 18$)$ and it is not our intention here to dabble into this issue.

The present study falls into the second category as it recognises several likely determinants of fixed investment expenditures in the setting of the Nigerian economy and employs those ones on which data are available in order to test for their impact. While most of the previous-studies focus on manufacturing sector investments alone, the present one embraces all the sectors in the economy and, like that of Bchrman (1972), is based on the premise that investment behaviour may differ from one sector to another. But unlike any previous study that has $f £$ vte $\mathrm{Jr}>\mathrm{rxtu}$ - jxrviire, this one alsojrocs further to analyse each of the main categories of investment, again on a sectoral basis. In addition to augmenting the prevailing few studies, on investment behaviour in a developing economy, we hope that the focus of this study on investment financing by foreign businesses will have the bonus effect of highlighting policy issues on foreign companies. The plan of the remaining part of this study is as follows: In section 2, we present the specification of our model, discussing those determinants which are of interest to our study. Section 3, contains the report and discussion of the empirical results of our model. Finally in section 4, we present the summary and conclusion of our paper.

\section{The Functional Specification of The Present Model}

We shall first discuss below the types of fixed investment expenditures to be studied and the variables that we postulate as their determinants. Then in 2.2 , we shall briefly present the format of regression equations that arc employed in estimating our model.

\section{TYPES OF FIXED INVESTMENT EXPENDITURES STUDIED AND THEIR POSTULATED DETERMINANTS}

Both the form of our model and the variables employed are dictated and severely constrained by non-availability of data. The available data on investments relate to only foreign companies. According to the published data, the whole economy (other than government activities) is divided into seven sectors viz: 


\section{Annals of the Social Council of Nigeria}

Mining and Quarrying; Manufacturing and Processing; Agriculture; Transport and Communications; Building and Construction; Trading and Business Services; and Miscellaneous (made up of consultancy firms, sub-contracts in relation to crude oil production, Agencies, as well as Insurance and Banking). For each of these seven sectors, we estimate, not only an aggregate gross investment expenditure equation, but also the component or constituent gross investment expenditure equations. These components of the aggregate gross investments are freehold and leasehold real estates; machinery and equipment; furniture and fixtures; and motor vehicles.

In each of the above specifications and subject to the constraint imposed by the afore-mentioned non-availability of data, the following explanatory variables are included in each gross investment expenditure equation:

(a) A single-period lagged value of gross capital stock: We specify a distributed lag of investment expenditure model as earlier pointed out in section 1 . This is accomplished by including a single-period lagged value of gross capital stock in an investment expenditure equation. The rationale for this is to make the model conform with the conventional partial adjustment model according to which a gap between the intended and actual capital stock is recognised. It is likely that the time horizon to completely implement the decision on accumulation of capital goods would exceed a year so that the one-period lagged value of gross capital stock should enter the corresponding investment expenditure equation with a coefficient that has a negative sign. However, as earlier mentioned in section 1, there is a reason for the one-period lagged value of the capital stock to enter the investment equation with a coefficient that has a positive value, based on the reason adduced by Wai and Wong (1982; 34 footnote 18).

(b) Change in sectoral output: The rationale for including the first difference of sectoral output has also been explained above. In the case of the miscellaneous sector, the GDP is used as a proxy for the sectoral output. This variable is entered in the equations with a lag of one period based on our contention that it is the observed change in sectoral output in the previous year that influences the investment decision in the current year.

(c) Relative price of capital services: This is the price index of the relevant category of capital stock divided by the price index applicable to the relevant sectoral output. Thus, in the case of the aggregate sectoral investment equations, the price index of the gross 
domestic investment expenditures is used as the numerator while the price index of the gross domestic output of the sector whose investment expenditure equation is being estimated is employed as the denominator. In the case of investment equations for the freehold and leasehold real estates, the price index of the gross domestic (or economywide) investment expenditures on building and construction is substituted as the numerator. In the case of machinery and equipment investment equations, the price index of the gross domestic (or economy-wide) investment expenditures on machinery and equipment is used as the denominator while the economy-wide price index of transport equipment is used instead in the case of the investment equations for motor vehicles. As there is no figure on the economy-wide price index on furniture and fixtures, we employed the relative capital price applicable to the plant and equipment investment as a proxy. In all the cases, the price index is computed by dividing the current value of the relevant variable as presented in the national accounts with the corresponding real value, i.e. the value measured in constant purchasing power. Finally, this variable is entered in the equations with a one-period lag based on our contention that it is the relative price of capital services prevailing in the preceding year that should influence the investment decision in the current year.

The relative price of capital, in this context, is a measure of the user cost of capital. The cost of borrowing (i.e. interest rate) is excluded for the conceptual reason adduced below. The inclusion of some balance sheet liability items precludes this. But apart from this conceptual reason, the observable rates of interest in developing countries do not normally reflect the true cost of borrowing due to the rudimentary nature of the capital markets and the pegging of interest rates much below the competitive rates by the authorities. Also, we did not adjust the relative price of capital for any anticipated capital gain (or loss) because of the difficulty encountered in its accurate computation from the available data.

(d) Foreign Reserves: We have also included this variable for the reason adduced earlier. Its performance in the various equations should throw some light on whether or not investment plans of the foreign firms in Nigeria are being constrained by the availability of foreign exchange to be rationed. This variable is also entered in the equations with a one-period lag because it is the foreign reserve position in the preceding period that should have the greatest impact on exchange controls that prevails in the current period and, hence, on the ability of firms to import capital goods in the current period. 
(e) Cash Flow Variables: We have separately included foreign short-term liability inflows and long-term liability inflows. These two categories of foreign sources of funds consist of trade and supplies credit; liabilities to the head office; and other foreign liabilities. The two are separately included as they might be differently utilised in financing the fixed investments.

As a measure of the internal finance, we also included the flow of depreciation funds (i.e. increase in the deemed funds set aside for replacement of capital stock). Secondly, we included changes in adjusted foreign capital funds (i.e. foreign share capital plus retained profits) as another measure of internal funds. Only about $15 \%$ of the change in adjusted capital funds constitute new capital issues (i.e. the newly raised capital from outside the business and which, therefore, do not constitute an internal source of funds) while the remaining $85 \%$ constitute the retained profits. As a result of the lack of sufficient data on these two items on a separate basis, the combined figures are taken to represent an internal source of funds.

In summary, eight explanatory variables are included in each equation. These are: the lagged value of capital stock; output; relative price of capital; foreign reserves; shortterm foreign. liability inflow; long-term foreign liability inflcw; flow of depreciation funds; and adjusted foreign capital inflow.

We did not include some conventional variables as reviewed earlier not only because of data non-availability but also because the inclusion of external sources of funds. This inclusion of external sources of funds has a conceptual implication in the sense that it precludes the simultaneous inclusion of those variables that influence the investment expenditures via their effects on those external sources of funds. For example, by including the credit flows, the inclusion of interest rate is thereby made redundant just as the inclusion of some other items on the liability side of the balance sheet should preclude a simultaneous inclusion of the Balance Sheet Risk Variable and even the Expected Profit Variable as these essentially affect the fixed investment expenditure flows through their effects on the flows of liability items. This conceptual requirement, which is sometimes complied with and sometimes violated by existing studies, has been aptly recognised and advocated for by Cohen $(1968 ; 2)$ who stressed that,

What is needed is financial market analysis in which interest rate and financial flows mutually determine each other. From the solution for financial markets, financial flows then become explanatory variables in expenditure equations.. As 
a result of this approach, financial flows replace interest rate in expenditure relationships and serve as 'equal partners' with internal sources.

\section{THE FORMAT OF REGRESSION EQUATIONS EMPLOYED IN ESTIMATING THE MODEL}

The linear regression equations fitted arc of the following form:

$\mathrm{Yt}=\mathrm{b}_{0}+\mathrm{b}_{1} \mathrm{X}_{1 \mathrm{t}}+\mathrm{b}_{2} \mathrm{X}_{2 \mathrm{t}}+\ldots \ldots \ldots \ldots \ldots \ldots \ldots+\mathrm{b}_{8} \mathrm{X}_{8 \mathrm{t}}+\mathrm{ut}$

where Yt is the gross investment expenditure in year is and XR is the $\mathrm{i}$ explanatory variable $(i=1,2, \ldots . .8)$ all of which have been discussed above.

The b's are the parameter estimates, while ut is the error term corresponding to the $\mathrm{Yt}$

We also tried to obtain common estimates of the coefficients for all the seven sectors combined by pooling the seven cross-sectional (i.e. sectoral) data and the 16 timescries data. To eliminate the factors that are characteristic of only some periods and only some sectors, we adopted the occurrence model of pooling the cross-sectional and timeseries data as described in Pindyok and Rubinfield (1981: 254-55). This is accomplished by introducing dummy explanatory variables which permit the intercept term to vary over the seven sectors and over the 16 annual periods as well. All the equations were estimated by the Ordinary Least Squares (OLS) method. The initial attempts to use Two-stage Least Squares (TSL) method in recognition of the possible two-way causal relationships between the fixed investment expenditures and the various categories of financial flows failed to produce materially different estimates.

\section{The Empirical Results}

\section{DATA SOURCES AND TIME DOMAIN}

Annual data over the period 1966 to 1982 were employed, resulting into 16 time-series observations. Data for earlier periods do not exist while data for post-1982 periods on foreign investments (which are published only after about four years) were not yet available at the lime of this study.

The source of data on foreign investment and finances is the Foreign Investment Surveys conducted by the Central Bank of Nigeria and published in its various issues of Economic and Financial Review which is also the source of the data on foreign reserves. On the other hand, figures on the various components of national accounts (including sectoral outputs arid figures on which the computations of relative price of capital were based) were derived from the Annual 
Abstract of Statistics and other supporting publications by the Nigerian Federal Office of Statistics.

All the variables quoted in naira are in millions and in current values. To recapitulate what has been indicated above, the relative price of capital, the change in sectoral output, and foreign reserves have all been included in the equations with a one-period lag.

\subsection{The Estimates}

The estimates of the equations are presented in Table I - V below. Table I presents the estimates of aggregate investments (i.e. all kinds of fixed investments combined) by sectors. Table II presents the estimates of the investment expenditures in freehold and leasehold real estates; Table III presents the estimates for machinery and equipment; Table IV presents the results for furniture and fittings; while Table V presents those of motor vehicles.

In each of the Tables I-V equation (1) to equation (7) are respectively for Mining and Quarrying; Manufacturing and Processing; Agriculture; Transport and Communications; Building and Construction; Trading and Business Services; and Miscellaneous sectors. Equation (8), on the other hand, represents the estimates of the pooled cross-section and times-series data as discussed earlier.

In all cases, the /-ratios are presented in the parentheses immediately below the coefficient estimates.

\subsection{COMMENTS ON THE EMPIRICAL RESULTS}

The estimates presented in Tables I - V above indicate fairly high values of the adjusted $\mathrm{R}$ in most cases. Also, the Durbin-Watson statistics, except in a few cases, are sufficiently so close to 2 that the presence of autocorrelation of residuals is not suggested. In respect of the performance of each explanatory variable, the following are the highlights:

(a) Lagged Value of Capital Stock The variable enters the equations negatively in most cases and their coefficient estimates are generally significant. However, the magnitudes of some coefficient estimates absolutely exceed unity, thereby preventing very plausible interpretations of the values.

(b) Change in Sectotal Output In all cases (with the exception of freehold and leasehold estate investment as well as motor vehicle investment expenditure equations in the building and construction sector), this variable enters the equations with coefficients having an implausible (negative) sign or insignificant 


\section{Table1}

\section{REGRESSION EQUATION ESTIMATES FOR AGGREGATE SECTORAL INVESTMENTS}

\begin{tabular}{|c|c|c|c|c|c|c|c|c|}
\hline & $\begin{array}{|ll|}0) & \text { Mining } \\
\& & \\
\text { Quarrying }\end{array}$ & \begin{tabular}{|l|}
$(2)$ \\
Manufacturi \\
ng \& \&
\end{tabular} & \begin{tabular}{|l|}
$3)$ \\
Agricultur \\
$e$
\end{tabular} & \begin{tabular}{|l|} 
(4) \\
Transport \\
$\& \quad$ Com- \\
munica- \\
tion
\end{tabular} & \begin{tabular}{|l|l|} 
(5) & \\
Building & $\&$ \\
Con- & \\
struction
\end{tabular} & \begin{tabular}{|l} 
(6) Trading \\
A Business \\
Services
\end{tabular} & $\begin{array}{l}(?) \\
\text { Miscella- } \\
\text { neous }\end{array}$ & $\begin{array}{l}\text { (8) Pooled } \\
\text { Equation }\end{array}$ \\
\hline Constant & 996 & 382 & -23 & -3 & 583 & 597 & -65 & - \\
\hline Lagged Level Form of & $\cdot 0.50$ & -0.36 & -0.28 & -0.06 & 0.03 & -015 & -0.07 & -0.061 \\
\hline Dependent Variable & $(2.0)$ & $(0.8)$ & $(1.5)$ & $(0.4)$ & $(0.1)$ & $(0.1)$ & $(0.6)$ & $(0.2)$ \\
\hline \multirow[t]{2}{*}{ Output } & 0.009 & -1.452 & 0.010 & 0.007 & -0.393 & -0.117 & -0.0002 & 0.0003 \\
\hline & $(0.2)$ & $(2.2)$ & $(1.4)$ & $(0.2)$ & $(0.7)$ & $(1.1)$ & $(0.8)$ & $(0.2)$ \\
\hline \multirow{2}{*}{ Relative Price of Capital } & -4.76 & 4.91 & 0.29 & 0.03 & -5.64 & -6.29 & -0.67 & 1.17 \\
\hline & $(1,7)$ & $(0.5)$ & $(1.4)$ & $(0.2)$ & $(0.8)$ & $(2.0)$ & (1.4) & $(1.8)$ \\
\hline \multirow[t]{2}{*}{ Foreign Reserves } & -0.078 & 0.231 & 0.003 & 0.0002 & 0.011 & 0.014 & 0.008 & 0.025 \\
\hline & $(1.2)$ & $(3.2)$ & $(1.3)$ & $(0.1)$ & $(0.3)$ & $(0.5)$ & (1.4) & $(0.0)$ \\
\hline \multirow[t]{2}{*}{ Depreciation Funds } & $0.2 \mathrm{~S}$ & 0.15 & 1.04 & 1.79 & 2.09 & 1.31 & 1.25 & 1.05 \\
\hline & $(0.5)$ & $(0.2)$ & $(3.7)$ & $(5.3)$ & $(1.7)$ & $(4.9)$ & (8.4) & $(9.0)$ \\
\hline \multirow[t]{2}{*}{ Short-term Liabilities } & 0.38 & -0.68 & 1.48 & -0.01 & -0.78 & 0.59 & 0.94 & 0.07 \\
\hline & $(0.4)$ & $(0.3)$ & $(0.7)$ & $(0.0)$ & $(0.1)$ & $(1.4)$ & (1.9) & $(0.2)$ \\
\hline \multirow[t]{2}{*}{ Long-term Liabilities } & -0.44 & -1.35 & -0.55 & 0.44 & 3.20 & 6.90 & -0.36 & 0.30 \\
\hline & $(1.2)$ & $(0.2)$ & $(0.2)$ & $(0.8)$ & ' $(0-9)$ & $(2.2)$ & $(0.6)$ & (1.6) \\
\hline \multirow[t]{2}{*}{ Adjusted Capital Funds } & 0.69 & 2.15 & 0.01 & 0.77 & 0.02 & -0.21 & 0.28 & -0.123 \\
\hline & $(0.5)$ & $(1.8)$ & $(0.1)$ & $(2.3)$ & $(0.0)$ & $(0.7)$ & (1.4) & $(0.5)$ \\
\hline Adjusted $\mathrm{R}^{2}$ & 0.66 & 0.86 & 0.68 & 0.74 & 0.22 & 0.87 & 0.99 & 0.62 \\
\hline Durbin- Watson Statistic & 2.1 & 2.1 & 1.8 & 2.5 & 2.6 & 2.0 & 3.3 & 2.3 \\
\hline
\end{tabular}


90 Annals of the Social Council of Nigeria

Table II

REGRESSION EQUATION ESTIMATES FOR SECTORAL INVESTMENT EXPENDITURES ON FREEHOLD \& LEASEHOLD ESTATE

\begin{tabular}{|c|c|c|c|c|c|c|c|c|}
\hline & \begin{tabular}{|l|}
$1)$ \\
Mining \& \\
Quarrying
\end{tabular} & $\begin{array}{l}\text { (2) } \\
\text { Manufacturi } \\
n g \\
\text { Processing }\end{array}$ & $\begin{array}{l}\text { (3) } \\
\text { Agricultur } \\
e\end{array}$ & \begin{tabular}{|l|}
$(4)$ \\
Transport \\
$\&$ \\
Communi \\
cation
\end{tabular} & \begin{tabular}{|l|} 
B) \\
Building $\quad \&$ \\
Con- \\
struction
\end{tabular} & $\begin{array}{l}\text { (6) } \\
\text { Trading A } \\
\text { Business } \\
\text { Services }\end{array}$ & $\begin{array}{l}(7) \\
\text { Miscella- } \\
\text { neous }\end{array}$ & $\begin{array}{l}\text { (8) Pooled } \\
\text { Equation }\end{array}$ \\
\hline Constant & 269 & 860 & 2 & 2 & 494 & 233 & 9 & - \\
\hline $\begin{array}{l}\text { Lagged Level Form of } \\
\text { Dependent Variable } \\
\text { Output }\end{array}$ & $\begin{array}{l}0.14 \\
(0.6) \\
-0.018 \\
(0-4)\end{array}$ & $\begin{array}{l}-0.95 \\
(2-2) \\
-0.530 \\
(1.0)\end{array}$ & $\begin{array}{l}-0.23 \\
(0.9) \\
-0.001 \\
(0.1)\end{array}$ & $\begin{array}{l}-0.16 \\
(0.9) \\
-0.004 \\
(0.3)\end{array}$ & $\begin{array}{l}-0.79 \\
(63) \\
0.344 \\
(3-1)\end{array}$ & $\begin{array}{l}-0.69 \\
(5.8) \\
\cdot 0.077 \\
(2.3)\end{array}$ & $\begin{array}{l}-0.17 \\
(13) \\
\text { O.OOX } \\
(0.3)\end{array}$ & $\begin{array}{l}0.34 \\
(4.2) \\
\bullet 0.008 \\
(2.2)\end{array}$ \\
\hline Relative Price of Capital & $\begin{array}{l}-1.15 \\
(0-5)\end{array}$ & $\begin{array}{l}-7.09 \\
(1.5)\end{array}$ & $\begin{array}{l}0.04 \\
(0.3)\end{array}$ & $\begin{array}{l}-0.02 \\
(0.2)\end{array}$ & $\begin{array}{l}-4.67 \\
(2.7)\end{array}$ & $\begin{array}{l}-1.93 \\
(1.9)\end{array}$ & $\begin{array}{l}-0.07 \\
(0.4)\end{array}$ & $\begin{array}{l}0.86 \\
(2.2)\end{array}$ \\
\hline Foreign Reserves & $\begin{array}{l}0.088 \\
(1-2)\end{array}$ & $\begin{array}{l}0.084 \\
(2-0)\end{array}$ & $\begin{array}{l}0.001 \\
(0.5)\end{array}$ & $\begin{array}{l}0.0001 \\
(0.1)\end{array}$ & $\begin{array}{l}0.074 \\
(4.0)\end{array}$ & $\begin{array}{l}0.052 \\
(6.2)\end{array}$ & \begin{tabular}{|l}
-0.002 \\
$(0.4)$
\end{tabular} & $\begin{array}{l}0.008 \\
(0.0)\end{array}$ \\
\hline Depreciation Funds & $\begin{array}{l}-0.83 \\
(1.3)\end{array}$ & $\begin{array}{l}-0.39 \\
(1.0)\end{array}$ & $\begin{array}{l}0.74 \\
(3.6)\end{array}$ & $\begin{array}{l}0.80 \\
(7.9)\end{array}$ & $\begin{array}{l}-1.11 \\
(3.3)\end{array}$ & $\begin{array}{l}0.53 \\
(6.1)\end{array}$ & $\begin{array}{l}0.82 \\
(8.7)\end{array}$ & $\begin{array}{l}0.13 \\
(13)\end{array}$ \\
\hline Short-term Liabilities & $\begin{array}{l}1.90 \\
(2.0)\end{array}$ & $\begin{array}{l}0.83 \\
(0.9)\end{array}$ & $\begin{array}{l}-0.58 \\
(0.4)\end{array}$ & $\begin{array}{l}-1.08 \\
(3.7)\end{array}$ & $\begin{array}{l}4.95 \\
(2.9)\end{array}$ & $\begin{array}{l}-0.10 \\
(0.9)\end{array}$ & $\begin{array}{l}0.26 \\
(0.8)\end{array}$ & $\begin{array}{l}0.26 \\
(1.3)\end{array}$ \\
\hline Long-term Liabilities & $\begin{array}{l}-0.58 \\
(1.6)\end{array}$ & $\begin{array}{l}-3.50 \\
(0.9)\end{array}$ & $\begin{array}{l}-1.47 \\
(0.7)\end{array}$ & $\begin{array}{l}0.56 \\
(3.4)\end{array}$ & $\begin{array}{l}-2.22 \\
(2-0)\end{array}$ & $\begin{array}{l}-0.81 \\
(0.8)\end{array}$ & $\mid \begin{array}{l}-0.22 \\
(0.4)\end{array}$ & $\begin{array}{l}-0.17 \\
(1.2)\end{array}$ \\
\hline Adjusted Capital Funds & $\begin{array}{l}1.69 \\
(1.2)\end{array}$ & $\begin{array}{l}1.47 \\
(23)\end{array}$ & $\begin{array}{l}0: 14 \\
(0.8)\end{array}$ & $\begin{array}{l}0.48 \\
(4.7)\end{array}$ & $\begin{array}{l}-3.13 \\
(2.3)\end{array}$ & $\begin{array}{l}0.05 \\
(03)\end{array}$ & $\begin{array}{l}0.15 \\
(0.8)\end{array}$ & $\begin{array}{l}0.21 \\
(1.3)\end{array}$ \\
\hline $\begin{array}{l}\text { Adjusted } \mathrm{R}^{2} \\
\text { Durbm-Watson Statistics }\end{array}$ & $\begin{array}{l}0.12 \\
1.8\end{array}$ & $\begin{array}{l}0.73 \\
2.7\end{array}$ & $\begin{array}{l}037 \\
2,1\end{array}$ & $\begin{array}{l}0.89 \\
2.8\end{array}$ & $\begin{array}{l}0.75 \\
1.2\end{array}$ & $\begin{array}{l}0.98 \\
1.6\end{array}$ & $\begin{array}{l}0.98 \\
2.5\end{array}$ & $\begin{array}{l}0.34 \\
2.4\end{array}$ \\
\hline
\end{tabular}


Table III

\section{REGRESSION EQUATION ESTIMATES FOR SECTORAL INVESTMENT EXPENDITURES ON MACHINERY \& EQUIPMENT}

\begin{tabular}{|c|c|c|c|c|c|c|c|c|}
\hline & \begin{tabular}{|l|}
1 (1) Mining \\
$\&$ \\
Quarrying
\end{tabular} & \begin{tabular}{|l|}
$(2)$ \\
Manufacturin \\
grocessing \\
Proce
\end{tabular} & \begin{tabular}{|l|}
$3)$ \\
Agricultur \\
$e$
\end{tabular} & \begin{tabular}{|l|}
$4)$ \\
Transport \\
$\&$ \\
Communic \\
ation
\end{tabular} & $\begin{array}{|lr|}\text { (5) } & \text { Building } \\
\& & \text { Con- } \\
\text { struction }\end{array}$ & $\begin{array}{l}\text { (6) Trading } \\
\& \text { Business } \\
\text { Services }\end{array}$ & $\begin{array}{l}\text { (7) } \\
\text { Miscella- } \\
\text { neous }\end{array}$ & $\begin{array}{l}\text { (8) Pooled } \\
\text { Equation }\end{array}$ \\
\hline Constant & 186 & 168 & 6 & -2 & 49 & 416 & -21 & - \\
\hline $\begin{array}{l}\text { Lagged Level Form of } \\
\text { Dependent Variable } \\
\text { Output }\end{array}$ & $\begin{array}{l}-0.27 \\
(1.2) \\
0.016 \\
(0-5)\end{array}$ & $\begin{array}{l}-0.83 \\
(2.9) \\
-0.719 \\
(1.8)\end{array}$ & $\begin{array}{l}-0.19 \\
(1.0) \\
0.001 \\
(\mathrm{OS})\end{array}$ & $\begin{array}{l}-0.49 \\
(0.7) \\
-0.013 \\
(0.7)\end{array}$ & $\begin{array}{l}043 \\
(23) \\
-0.020 \\
(0.4)\end{array}$ & $\begin{array}{l}-0.66 \\
(4.0) \\
-0.012 \\
(0.2)\end{array}$ & $\begin{array}{l}0.39 \\
(2-5) \\
-0.002 \\
(1.6)\end{array}$ & $\begin{array}{l}-0.05 \\
(0.9) \\
0.001 \\
(0.3)\end{array}$ \\
\hline Relative Price of Capital & $\begin{array}{l}-0.03 \\
(0.4)\end{array}$ & $\begin{array}{l}2.96 \\
(1.5)\end{array}$ & $\begin{array}{l}0.08 \\
(0.9)\end{array}$ & $\begin{array}{l}0.05 \\
(0.6)\end{array}$ & $\begin{array}{l}-0.49 \\
(1.0)\end{array}$ & $\begin{array}{l}-4.42 \\
(3-0)\end{array}$ & $\begin{array}{l}0.15 \\
(I S)\end{array}$ & $\begin{array}{l}-0.04 \\
(0.1)\end{array}$ \\
\hline Foreign Reserves & $\begin{array}{l}0.036 \\
(0.7)\end{array}$ & $\begin{array}{l}0.149 \\
(3.4)\end{array}$ & $\begin{array}{l}0.001 \\
(0.5)\end{array}$ & $\begin{array}{l}0.002 \\
(1.7)\end{array}$ & $\begin{array}{l}0.019 \\
(2.3)\end{array}$ & $\begin{array}{l}-0.008 \\
(0.5)\end{array}$ & $\begin{array}{l}0.002 \\
(0.8)\end{array}$ & $\begin{array}{l}0.008 \\
(0.0)\end{array}$ \\
\hline Depreciation Funds & $\begin{array}{l}0.65 \\
(1.6)\end{array}$ & $\begin{array}{l}-0.47 \\
(I S)\end{array}$ & $\begin{array}{l}0.33 \\
(2.4)\end{array}$ & $\begin{array}{l}0.62 \\
(3.1)\end{array}$ & $\begin{array}{l}1.65 \\
(11.8)\end{array}$ & $\begin{array}{l}0.25 \\
(1.9)\end{array}$ & $\begin{array}{l}0.63 \\
(9.3)\end{array}$ & $\begin{array}{l}050 \\
(7.6)\end{array}$ \\
\hline Short-term Liabilities & $\begin{array}{l}-0.66 \\
(0.9)\end{array}$ & $\begin{array}{l}-0.22 \\
(0.3)\end{array}$ & $\begin{array}{l}1.67 \\
(1.6)\end{array}$ & $\begin{array}{l}-0.78 \\
(1-5)\end{array}$ & $\begin{array}{l}-0.61 \\
(0.9)\end{array}$ & $\begin{array}{l}0.64 \\
(2.4)\end{array}$ & $\begin{array}{l}-0.15 \\
(0.8)\end{array}$ & $\begin{array}{l}0.10 \\
(0.6)\end{array}$ \\
\hline Long-term Liabilities & $\begin{array}{l}0.62 \\
(2.5)\end{array}$ & $\begin{array}{l}-3.44 \\
(1-5)\end{array}$ & $\begin{array}{l}1.83 \\
(1.2)\end{array}$ & $\begin{array}{l}-0.12 \\
(0.4)\end{array}$ & $\begin{array}{l}1.55 \\
(3-5)\end{array}$ & $\begin{array}{l}-5.67 \\
(2.9)\end{array}$ & $\begin{array}{l}-1.43 \\
(4.7)\end{array}$ & $\begin{array}{l}0.39 \\
(3.4)\end{array}$ \\
\hline Adjusted Capital Funds & $\begin{array}{l}-0.78 \\
(0.9)\end{array}$ & $\begin{array}{l}1.96 \\
(3.8)\end{array}$ & $\begin{array}{l}-0.04 \\
(0.3)\end{array}$ & $\begin{array}{l}0.09 \\
(0.4)\end{array}$ & $\begin{array}{l}0.59 \\
(1.3)\end{array}$ & $\begin{array}{l}0.01 \\
(0.0)\end{array}$ & $\begin{array}{l}0.12 \\
(1.4)\end{array}$ & $\begin{array}{l}-0.22 \\
(1.6)\end{array}$ \\
\hline Adjusted $\mathrm{R}^{2}$ & 0.53 & 0.79 & 0.61 & 0.78 & 0.96 & 0.74 & 0.98 & 056 \\
\hline Durbin-Watson Statistics & 2.4 & 2.8 & 1.8 & 3.0 & 2.3 & 1.0 & 1.8 & 2.4 \\
\hline
\end{tabular}


Table IV

\section{REGRESSION EQUATION ESTIMATES FOR SECTORAL INVESTMENT EXPENDITURES ON FURNITURE \& FIXTURES}

\begin{tabular}{|c|c|c|c|c|c|c|c|c|}
\hline & $\begin{array}{l}\text { (1) Mining } \\
\& \\
\text { Quarrying }\end{array}$ & \begin{tabular}{|lr}
$(2)$ \\
Manufacturin \\
$g$ & -4 \\
Processing
\end{tabular} & \begin{tabular}{|l} 
(3) \\
Agriculture
\end{tabular} & \begin{tabular}{|l|}
$(4)$ \\
Transport \\
$<\& \quad$ Com- \\
munication
\end{tabular} & $\begin{array}{lr}\text { (5) } & \text { Building } \\
\& . & \text { Con- } \\
\text { struction }\end{array}$ & $\begin{array}{l}\text { (6) Trading } \\
\& \text { Business } \\
\text { Services }\end{array}$ & $\begin{array}{l}(7) \\
\text { Miscella- } \\
\text { neous }\end{array}$ & $\begin{array}{l}\text { (8) Pooled } \\
\text { Equation }\end{array}$ \\
\hline Constant & 0 & 65 & 0 & 0 & 50 & 7 & 7 & - \\
\hline $\begin{array}{l}\text { Lagged Level Form of } \\
\text { Dependent Variable }\end{array}$ & $\mid \begin{array}{l}0.22 \\
(0.6)\end{array}$ & $\begin{array}{l}-1.85 \\
(3.0)\end{array}$ & $\begin{array}{l}-0.67 \\
(3.2)\end{array}$ & $\begin{array}{l}-0.74 \\
\text { fr-9) }\end{array}$ & $\begin{array}{l}-0.47 \\
(1.2)\end{array}$ & $\begin{array}{l}0.03 \\
(0.1)\end{array}$ & $\begin{array}{l}-0.70 \\
(2.4)\end{array}$ & $\begin{array}{l}-0.30 \\
(2.6)\end{array}$ \\
\hline Output & 0.002 & -0.222 & -0.0004 & -0.007 & -0.059 & -0.018 & -0.008 & $\cdot 0.001$ \\
\hline Relative Price of Capital & $\begin{array}{l}(0.1) \\
-0.003 \\
(0.0)\end{array}$ & $\begin{array}{l}(1.2) \\
\bullet 0513 \\
(0.6)\end{array}$ & $\begin{array}{l}(0.3) \\
0.023 \\
(0.6)\end{array}$ & $\begin{array}{l}(1.0) \\
0.011 \\
(0.3)\end{array}$ & $\begin{array}{l}(1.6) \\
-0.451 \\
(1.0)\end{array}$ & $\begin{array}{l}(0.9) \\
-0.032 \\
(0.1)\end{array}$ & $\begin{array}{l}(0.9) \\
-0.047 \\
(1.0)\end{array}$ & $\begin{array}{l}(1.1 \\
0.114 \\
(1.2)\end{array}$ \\
\hline Foreign Reserves & $\begin{array}{l}\cdot 0.001 \\
(0.2)\end{array}$ & $\begin{array}{l}0.045 \\
(2.2)\end{array}$ & $\begin{array}{l}0.0001 \\
(0.1)\end{array}$ & $\begin{array}{l}0.001 \\
(2.4)\end{array}$ & $\begin{array}{l}0.008 \\
(13)\end{array}$ & $\begin{array}{l}0.010 \\
(1.6)\end{array}$ & $\begin{array}{l}-0.001 \\
(0.7)\end{array}$ & $\begin{array}{l}0.004 \\
(0.0)\end{array}$ \\
\hline Depreciation Funds & $\begin{array}{l}0.04 \\
(1.6)\end{array}$ & $\begin{array}{l}-0.16 \\
(13)\end{array}$ & $\begin{array}{l}-0.06 \\
(1.0)\end{array}$ & $\begin{array}{l}0.07 \\
(0.8)\end{array}$ & $\begin{array}{l}-0.06 \\
(05)\end{array}$ & $\mid \begin{array}{l}\cdot 0.11 \\
(2.6)\end{array}$ & $\begin{array}{l}0.04 \\
(1.6)\end{array}$ & $\begin{array}{l}0.04 \\
(2.0)\end{array}$ \\
\hline Short-term Liabilities & $\begin{array}{l}-0.14 \\
(2.7)\end{array}$ & $\begin{array}{l}0.27 \\
(0.8)\end{array}$ & $\begin{array}{l}0.02 \\
(0.0)\end{array}$ & $\begin{array}{l}0.16 \\
(0.8)\end{array}$ & $\begin{array}{l}0.19 \\
(03)\end{array}$ & $\begin{array}{l}\bullet 035 \\
(4.1)\end{array}$ & $\begin{array}{l}-0.05 \\
(05)\end{array}$ & $\begin{array}{l}-0.08 \\
(1.4)\end{array}$ \\
\hline Long-term Liabilities & $\begin{array}{l}-0.002 \\
(0.1)\end{array}$ & $\begin{array}{l}\mathrm{J} 0.71 \\
(0.7)\end{array}$ & $\begin{array}{l}-158 \\
(2.3)\end{array}$ & $\begin{array}{l}0.24 \\
(1.8)\end{array}$ & $\begin{array}{l}0.08 \\
(0-2)\end{array}$ & $\begin{array}{l}051 \\
(0.6)\end{array}$ & $\begin{array}{l}0.36 \\
(2.4)\end{array}$ & $\begin{array}{l}-0.02 \\
(0.6)\end{array}$ \\
\hline Adjusted Capital Funds & $\begin{array}{l}-0.06 \\
(13)\end{array}$ & $\begin{array}{l}0.66 \\
(23)\end{array}$ & $\begin{array}{l}0.02 \\
(04)\end{array}$ & $\begin{array}{l}0.14 \\
(1.7)\end{array}$ & $\begin{array}{l}\cdot f l .15 \\
(0.4)\end{array}$ & $\begin{array}{l}0.18 \\
(2-8)\end{array}$ & $\begin{array}{l}0.07 \\
(1.4)\end{array}$ & $\begin{array}{l}-0.00 \\
(0.0)\end{array}$ \\
\hline Adjusted $\mathrm{R}^{2}$ & 057 & 0.64 & 053 & 0.71 & 0.40 & 057 & 0.87 & 0.11 \\
\hline Durbin-Watson Statistics & 2.7 & 3.1 & 2.7 & 1.7 & 2.0 & 15 & 15 & 2.0 \\
\hline
\end{tabular}


Table V

\section{REGRESSION EQUATION ESTIMATES FOR SECTORAL INVESTMENT EXPENDITURES ON MOTOR VEHICLES}

\begin{tabular}{|c|c|c|c|c|c|c|c|c|}
\hline & \begin{tabular}{|l|l|}
$(1) \quad$ Mining \\
$\&$ \\
Quarrying
\end{tabular} & \begin{tabular}{|l} 
Manufacturing \\
\& Processing
\end{tabular} & $\begin{array}{l}\text { (3) } \\
\text { Agriculture }\end{array}$ & \begin{tabular}{|l|}
$4)$ \\
Transport \& \\
Communica- \\
tion
\end{tabular} & $\begin{array}{|lr|}(5) & \text { Building } \\
\& & \text { Con- } \\
\text { struction }\end{array}$ & $\begin{array}{|lr|}(6) & \text { Trading } \\
\& & \text { Business } \\
\text { Services }\end{array}$ & $\begin{array}{l}\text { (7) Miscella- } \\
\text { neous }\end{array}$ & $\begin{array}{l}\text { (8) } \quad \text { Pooled } \\
\text { Equation }\end{array}$ \\
\hline Constant & 35 & 2 & -2 & 17 & -40 & 82 & 8 & - \\
\hline $\begin{array}{l}\text { Lagged Level Form of } \\
\text { Dependent Variable }\end{array}$ & $\begin{array}{l}-0.39 \\
(05)\end{array}$ & $\begin{array}{l}-0.04 \\
(2.3)\end{array}$ & $\begin{array}{l}-1.47 \\
(3.2)\end{array}$ & $\begin{array}{l}-0.78 \\
(1.9)\end{array}$ & $\begin{array}{l}0.24 \\
(2.2)\end{array}$ & $\begin{array}{l}-0.08 \\
(0.7)\end{array}$ & $\begin{array}{l}-154 \\
(2.9)\end{array}$ & $\begin{array}{l}-0.22 \\
(2.2)\end{array}$ \\
\hline Output & $\begin{array}{l}-0.013 \\
(0.8)\end{array}$ & $\begin{array}{l}-0.156 \\
(2.1)\end{array}$ & $\begin{array}{l}0.002 \\
(0.6)\end{array}$ & $\begin{array}{l}0.031 \\
(0.8)\end{array}$ & $\begin{array}{l}0.069 \\
(2.0)\end{array}$ & $\begin{array}{l}-0.046 \\
(4.0)\end{array}$ & $\begin{array}{l}0.0002 \\
(0.6)\end{array}$ & $\begin{array}{l}-0.001 \\
(1.3)\end{array}$ \\
\hline Relative Price of Capital & $\begin{array}{l}-0.23 \\
(0.2)\end{array}$ & $\begin{array}{l}0.18 \\
(0.4)\end{array}$ & $\begin{array}{l}0.05 \\
(0.8)\end{array}$ & $\begin{array}{l}-0.16 \\
(0.6)\end{array}$ & $\begin{array}{l}0.40 \\
(1.1)\end{array}$ & $\begin{array}{l}-0.95 \\
(3.4)\end{array}$ & $\begin{array}{l}-0.05 \\
(0.8)\end{array}$ & $\begin{array}{l}0.21 \\
(1.5)\end{array}$ \\
\hline Foreign Reserves & $\begin{array}{l}0.002 \\
(1.0)\end{array}$ & $\begin{array}{l}0.036 \\
(3.7)\end{array}$ & $\begin{array}{l}0.001 \\
(1.4)\end{array}$ & $\begin{array}{l}0.0003 \\
(0.2)\end{array}$ & $\begin{array}{l}-0.010 \\
(2-1)\end{array}$ & \begin{tabular}{|l}
0.008 \\
$(3.2)$
\end{tabular} & $\begin{array}{l}0.000 \\
(0.0)\end{array}$ & $\begin{array}{l}0.009 \\
(0.0)\end{array}$ \\
\hline Depreciation Funds & $\begin{array}{l}-0.05 \\
(0.3)\end{array}$ & $\begin{array}{l}-0.14 \\
(1.9)\end{array}$ & $\begin{array}{l}-0.08 \\
(0.9)\end{array}$ & $\begin{array}{l}0.22 \\
(0.6)\end{array}$ & $\begin{array}{l}0.73 \\
(9.1)\end{array}$ & $\begin{array}{l}0.02 \\
(0.9)\end{array}$ & $\begin{array}{l}-0.05 \\
(1.2)\end{array}$ & $\begin{array}{l}0.07 \\
(3.2)\end{array}$ \\
\hline Short-term Liabilities & $\begin{array}{l}-0.55 \\
(1.4)\end{array}$ & $\begin{array}{l}-0.04 \\
(0.3)\end{array}$ & $\begin{array}{l}0.44 \\
(0.6)\end{array}$ & \begin{tabular}{|l}
-0.03 \\
$(0.0)$
\end{tabular} & $\begin{array}{l}-1.45 \\
(3.9)\end{array}$ & $\begin{array}{l}-0.03 \\
(0.7)\end{array}$ & $\begin{array}{l}0.15 \\
(1.4)\end{array}$ & $\begin{array}{l}-0.14 \\
(2.4)\end{array}$ \\
\hline Long-term Liabilities & $\begin{array}{l}\text { a.oi } \\
(0.0)\end{array}$ & $\begin{array}{l}-0.17 \\
(0.4)\end{array}$ & $\begin{array}{l}0.81 \\
(0.7)\end{array}$ & $\begin{array}{l}-0.10 \\
(0.2)\end{array}$ & $\begin{array}{l}0.65 \\
(3.1)\end{array}$ & $\begin{array}{l}-0.87 \\
(2.7)\end{array}$ & $\begin{array}{l}0.59 \\
(3.2)\end{array}$ & $\begin{array}{l}0.64 \\
(0.9)\end{array}$ \\
\hline Adjusted Capital Funds & $\begin{array}{l}0.41 \\
(1.0)\end{array}$ & $\begin{array}{l}0.34 \\
(2.1)\end{array}$ & $\begin{array}{l}-0.06 \\
(0.6)\end{array}$ & $\begin{array}{l}0.06 \\
(0.1)\end{array}$ & $\begin{array}{l}0.34 \\
(1.5)\end{array}$ & $\begin{array}{l}, 0.01 \\
(0.1)\end{array}$ & $\begin{array}{l}0.02 \\
(0.4)\end{array}$ & $\begin{array}{l}0.06 \\
(1.2)\end{array}$ \\
\hline $\begin{array}{l}\text { Adjusted } \mathrm{R}^{2} \\
\text { Durbin-Watson Statistics }\end{array}$ & $\begin{array}{l}0.34 \\
2.0\end{array}$ & $\begin{array}{l}055 \\
2.0\end{array}$ & $\begin{array}{l}0.56 \\
2.2\end{array}$ & $\begin{array}{l}0.01 \\
2.6\end{array}$ & $\begin{array}{l}0.91 \\
1.9\end{array}$ & $\begin{array}{l}0.67 \\
2.0\end{array}$ & $\begin{array}{l}0.90 \\
2.0\end{array}$ & $\begin{array}{l}0.33 \\
2.1\end{array}$ \\
\hline
\end{tabular}




\section{Annals of the Social Council of Nigeria}

values. This suggests that changes in outputs do not generally influence the fixed private investment expenditures. This observation is in line with our a priori knowledge of the economy where the firms are operating under very low capacity utilisation rates which are generally below $50 \%$ of the installed capacities. This means that firms are unlikely to embark on expansion plans in order to produce the required increase in output. A policy implication of output expansion might not have the full multiplier effect since they are not likely to engender a corresponding increase in investment expenditures by the business sector.

(c) Relative Price of Capital With a few exceptions, this variable has either implausible or insignificant coefficient influence on fixed investment expenditures. A policy implication of this is that subsidies in the price of capital goods and other fiscal measures that reduce the price of capital goods confronting the firms is likely to be feeble and impotent in increasing the business expenditure on capital goods.

(d) Foreign Reserves This variable enters the various Manufacturing Processing sectoral investment expenditure equations with significantly positive coefficients, suggesting that foreign exchange rationing is an important constraint on the ability to implement investment plans in this sector. In some cases, the same result is also applicable to the Building and Construction sector as well as the Business Services sector. The non-significance of this variable in most other cases can be explained by the fact that the foreign companies were able to procure the foreign exchange required to finance the imported capital goods from their head offices and parent companies abroad. The relevance of this finding is that policy measures should not be concerned with how the expatriate business firms can procure foreign exchange since they appear to be able to cater for their foreign exchange requirements presumably through the assistance of their head offices and parent companies abroad.

(e) Depreciation Funds This is the only variable that consistently and significantly enters almost all the equations with the expected positive sign. Thus, the evidence supports the contention that investment outlays by these foreign firms were substantially being financed by this category of internal source of funds.

(f) Adjusted Capital Funds As mentioned in the previous section, this variable is about $85 \%$-composed of increase in retained earnings. In most cases, it enters the equations with the expected positive coefficients whose values are significant in 
about half of the cases. In particular, this source of internal funds appears to have been more used in financing the freehold and leasehold estate investment outlays as reported in Table II. Thus, incomes policy that reduces dividend distribution, and hence, increases the retained earning, should have the effect of increasing the expenditure of the firms on capital goods.

(g) Inflow of Short-Term Foreign Liabilities Except in a very few cases, this variable enters the equations with coefficients having either an unexpected (negative) sign or insignificant values. The conclusion from this observation is that the short-term foreign capital inflows are not often used in financing domestic capital formation. This is in accordance with the conventional theory of finance which requires shortterm liabilities to be mainly used in financing short-term assets (or working capital) as opposed to fixed assets.

(h) Inflow of Long-Term Foreign Liabilities What has been said in respect of the inflow of short-term foreign liabilities equally applies here and this also suggests that the long-term foreign capital inflows have little impact on domestic capital formation.

\section{Summary and Conclusion}

The important roles played by fixed investment expenditures in mac-roeconomic policies have prompted several studies on investment behaviour. These studies, which have been confined to the advanced countries, entail several dimensions, the most commonly emphasised of which is the examination of those factors that determine the desired level of capital stock. For this reason and practical expediency dictated by the paucity of data, the present study has focused on this (most emphasised) dimension. Apart from augmenting the few existing studies on this subject in the context of developing countries, the present work has also extended the scope by investigating the determinants of the various components of fixed investment expenditures for each of the seven components in the private sector of the economy viz:. Mining and Quarrying; Manufacturing and Processing; Agriculture; Transport and Communications; Building and Construction; Trading and Business Services; and Miscellaneous.

Having reviewed the Various main determinants of investment expenditures that have been identified in the literature, we selected some of them in order to explain the investment expenditures of various categories as indicated above. Annual data over the period 1966 to 1982 were employed. Our scope was confined to foreign companies operating in Nigeria. The reason is by data non-availability - a factor 
which also dictated the choice of the variables we employed in explaining the variations in the investment expenditures.

Our findings suggest that changes in sectoral outputs do not influence investment expenditures - an observation that can be explained by the prevalent low rate of capacity utilisation. Moreover, changes in the price of capital goods in relation to the price of output have been found to have little or no influence on the investment expenditures. On the other hand, foreign exchange, rationing has been found in some cases, especially in the manufacturing sector, to constitute a constraint on the ability of the firms to implement their investment plans. However, this influence of foreign reserve availability was not found to be as pronounced as might have been expected. The reason for this is the likely easy access which these foreign companies, have to foreign exchange through connections with their foreign branches and parent-companies. The internal sources of funds in the form of retained earnings and, especially depreciation funds, constitute the most important sources of financing the investment expenditures. The inflows of foreign short-term and long-term liabilities were not found to be used in financing domestic capital formation.

While our empirical findings as reported in this study and summarised above may be lacking in precision and, therefore need to be treated with some caution, especially because of the published data inaccuracies, we nevertheless hope that the results indicate general directions of the effects of the several variables employed on fixed investment expenditures.

\section{Notes}

The orthodox method of pooling the time-series and cross-section data is employed. As a very brief restatement of this method, this means that the first 16 annual observations in respect of each variable (i.e. from 1967 to 1982) for the first sector constitute observations 1 to 16 , those for the second sector constitute observations 17 to 32 etc, until the 16 annual observations for the seventh and last sector that constitutes observations 97 to 112 . 
Foreign Companies in Nigeria: Fixed Investment Expenditures 97

\section{References}

Akinnifesi, E. O.: 'Determinants of Private Foreign Investment in Nigerian Manufacturing Industries', Central Bank of Nigeria's Economic A financial Review, June 1981.

Behrman, J. R.: 'Sectoral Investment Determination in a Developing Economy', American Economic Review. 825-41,1972.

Bulsboirow, R. E.: 'The Determinants of Fixed Investments by Manufacturing Finns in a Developing Country*, International Economic Review, 18: 697-717,1977.

Chenery, H. B.: 'Over-Capacity and the Acceleration Principle', Econometri-ca, 20:1-28,1952.

Clark, J. M.: 'Business Acceleration and the Law of Demand: A Technical Factor in Economic Cycles', Journal of Political Economy. 25: p. 217-35, 1917.

Cohen, J. : 'Integrating the Real and Financial via the Linkage of Financial Flow", Journal of Finance, 23: 2-27,1968.

Eisner, R. and Strotz R. H.: 'Determinants of Business Investment' in Commission on Money and Credit, Impacts of Monetary Policy, Englewood Cliffs, N. J., 1963.

Jorgenson, D. W. : The Theory of Investment Behaviour' in R. Ferber (ed), Determinants of Investment Behaviour, New York: National Bureau of Economic Research: 129-255,1967.

: 'Econometric Studies of Investment Behaviour: A Survey*, Journal of Economic Literature, 9:1111-47,1971.

Keynes, M. : The General Theory of Employment, Interest and Money, London: Macmillan, 1936.

Koyck, L. M.: Distributed Lags and Investment Analysis, North-Holland Amsterdam, 1954.

Leff, N. H. and Sato, K.: 'Macroeconomic Adjustments in Developing Countries: Instability, Short-run Growth, and External Dependency*, The Review of Economics and Statistics, 1980. Lund, P. J.: Investment: The Study of an Economic Aggregate, San Francisco: Holden-Day, 1971.

Meyer, J. and Kuh, E. : The Investment Decision, Cambridge Mass: Havard University Press, 1957. 


\section{Annals of the Social Council of Nigeria}

Pyndick, R. S. and Rubinfeld, D. L. : Econometric Models and Economic Forecasts. New York: McGraw Hill International, 1981.

Rowley, J. C. R. and Trivedi, P. K. : Econometrics of Investment. New York: John WUley \& Sons, 1975.

Wai, Tun U. and Chorng-huey Wong, : 'Determinants of Private Investment in Developing Countries', The Journal of Developing Studies 19-36,1982. 